\title{
An Examination of the Present and Predictions for the Future of Intercollegiate Athletics
}

\author{
James T Morton \\ Ithaca College \\ Donna L. Pastore \\ The Ohio State University
}

Abstract: This study forecasts future administrative issues in the National Collegiate Athletic Association (NCAA) Division I Football Bowl Subdivision (FBS) of intercollegiate athletics. The research design employed the Delphi technique to survey an expert panel consisting of 12 athletic directors and associate athletic directors from FBS institutions over three rounds to ascertain what issues are likely to occur over the next five to seven years and whether or not these issues will have a significant impact on the way intercollegiate athletics operates. Results of the study revealed eight issues that were likely to occur over the next five to seven years. Four of these issues related to the economic sector of the environment, three related to the sociocultural domain, and one related to the legal sector. Furthermore, 14 of the issues were rated by the expert panel as having a significant level of impact if they were to occur. Recommendations for intercollegiate athletics administrators and researchers are made based on the forecasts by the expert panel.

Keywords: intercollegiate athletics, Delphi technique, forecasting

Intercollegiate athletics in the United States is a dynamic enterprise facing myriad challenges in both the immediate and long-term future. The largest organization in intercollegiate athletics that will be taking on these challenges is the National Collegiate Athletic Association (NCAA). The NCAA was formed in 1906 in reaction to calls for the abolition of football due to violence resulting in multiple deaths the year prior (Smith, 2011). Since its inception, the NCAA has undergone multiple reforms and attempted reforms due to both internal and external pressures. For example, the implementation of Title IX, a federal law that prohibits discrimination on the basis of sex in education programs receiving federal financial assistance (United States Department of Education, n.d., para. 1), caused intercollegiate athletics programs to begin offering more opportunities for women to participate in athletics. While this reform stemmed from the government, its enforcement also required many efforts from students and administrators within intercollegiate athletic programs (Wushanley, 2004). Similarly, it is important for those in leadership positions within the NCAA to understand the future consequences for different stakeholder groups based on the current set of internal and external pressures (Branch \& Crow, 1994).

The NCAA "is a membership-driven organization dedicated to safeguarding the well-being of student-athletes and equipping them with the skills to succeed on the playing field, in the 
classroom and throughout life" (NCAA, 2015, Who We Are para. 1). This membership is comprised of a group of colleges and universities with athletics programs throughout the United States and Canada. The NCAA consists of three divisions, designated as Division I, Division II, and Division III. Division I members that sponsor football are broken into two subdivisions: Football Bowl Subdivision (FBS) and Football Championship Subdivision (FCS). Members of the FBS are differentiated by, among other criterion, the amount of money they invest in athletics, and the total number of sports in which they sponsor (NCAA, 2018). As a collective, the institutions comprising the FBS group are undergoing unprecedented change during the second decade of the $21^{\text {st }}$ century. Specifically, the changes focus on student-athlete well-being and the potential consequences stemming from the results of student-athlete led litigation.

The NCAA and its member institutions are adjusting their approach to the treatment of student-athletes by allocating more resources to student-athlete well-being than performance. One critical example of this is a change in policy related to athletic scholarships. Institutions are now allowed to provide additional money to the athletic scholarship based on what each institution determines is the full cost of attendance. Prior to this allowance, institutions were limited to paying for tuition, room and board, books, and fees. This full cost of attendance measure allows institutions to give student-athletes money as part of their scholarship that covers expenses beyond tuition, room and board, and books (NCAA, 2018). Another significant change that has taken place is the allowance of more meals that are provided by the institution for student-athletes, as outlined in section 16 of the NCAA manual (NCAA, 2018). Also aimed at improving student-athlete wellbeing is the allowance of multi-year scholarships compared to allowing only one-year, renewable scholarships. This adjustment was brought about by the idea that student-athletes should be protected from losing their scholarship for poor play or injury (Solomon, 2014). These policy shifts toward an improved student-athlete experience can be traced to two major catalysts: NCAA governance structure modifications and legal actions being pursued by current and former studentathletes.

In 2013, the NCAA formed a steering committee to recommend changes to the Division I governance structure (NCAA, 2014). The most drastic change that the committee recommended was granting autonomy to institutions in the Power 5 conferences, i.e., Atlantic Coast Conference, Big Ten Conference, Big 12 Conference, Pacific 12 Conference, and Southeastern Conference, to create policies related to the use of resources on student-athlete well-being. This autonomy allowed for an increase in money expenditure on student-athlete-centric initiatives by limiting the necessary votes on this type of legislation to members of these conferences, thereby blocking lesser-resourced programs from voting down such cost-inducing initiatives.

The NCAA membership reacted to the legal actions being pursued by current and former student-athletes who felt more of the revenues generated by college athletics should be devoted to the student-athletes. Under the current structure, when revenues increase, those increases are commonly used to increase coaches' salaries, build and enhance facilities, and add personnel to departments. Ed O'Bannon, a former men's basketball student-athlete at the University of California, Los Angeles (UCLA), filed suit against the NCAA and a video game company in 2009 for using his likeness without compensation (O'Bannon v. National Collegiate Athletic Association, 2014). This lawsuit made the case that the NCAA and its membership were profiting off of the names, images, and likenesses (NIL) of student-athletes, and not compensating them for 
it. In 2014, a judge ruled in favor of O'Bannon and ordered NCAA Division I Football Bowl Subdivision (FBS) member institutions to set aside money in a trust for football and men's basketball student-athletes to receive upon leaving the institution with a $\$ 5,000$ cap per year per athlete (O’Bannon v. NCAA, 2014). Although reversed upon appeal, this lawsuit brought national attention to the idea of compensating student-athletes beyond just an athletic scholarship and inspired similar lawsuits brought by student-athletes against the NCAA in an effort to have more of the resources generated by the NCAA and its member institutions allocated to student-athlete well-being (e.g., Alston v. NCAA, Jenkins v. NCAA, Keller v. NCAA; Litan \& Keith, 2014). The plaintiff in the Alston case was seeking compensation for student-athletes who participated but did not receive the cost of attendance stipend for the entirety of their intercollegiate athletics eligibility. The case was settled for over $\$ 208$ million and required payment to athletes who competed in NCAA Division I men's and women's basketball and FBS football (Alston v. NCAA, 2017). The plaintiffs in the Jenkins case are currently seeking an injunction against the NCAA and its members that would prohibit them from setting a limit on the value of an athletic scholarship (Jenkins v. NCAA, 2014). If the Jenkins case is decided for the plaintiffs, it would create a free market that would allow schools to offer any amount of compensation they choose to prospective studentathletes.

The combination of Power 5 autonomy and legal actions taken against the NCAA has increased the focus on student-athletes. This represents a shift in philosophy for member institutions of the NCAA, as prior to these changes most legislation was aimed at competitive equity (Smith, 2011; Weaver, 2015). While there is an increased focus on student-athletes, they are just one of many stakeholders involved in and affected by intercollegiate athletics.

\section{Literature Review}

Research has been conducted on forecasting issues in intercollegiate athletics to assess the future environment (Branch \& Crow, 1994; Drain \& Ashley, 2000; Pastore \& Schneider, 2004). However, with the rapidity and breadth of current changes, such as conference realignment, Power 5 autonomy, and multiple legal proceedings taking place in the NCAA, this study aimed to add to the body of literature by assessing the current state of the environment and by forecasting how current changes will affect the future environment in which the NCAA and its membership operate over the next five to seven years. It is the goal of this research to aid institutions in producing a strategic plan that will assist in accomplishing their stated mission in the most effective way possible (Bryson, 2011; Glaister \& Falshaw, 1999; Yow, Migliore, Bowden, Stevens, \& Loudon, 2000).

When assessing an organization's environment, it is important to identify the factors that comprise the environment. The external environment of an organization consists of factors that can create opportunities or impose threats (Daft, 2004; Slack \& Parent, 2006). A common approach to examining these factors is the PESTEL framework of political, economic, sociocultural, technological, ecological, and legal factors (Rothaermel, 2017). The PESTEL framework is a "mnemonic used in strategic management to group macro-environment factors to help strategists look for sources of general opportunity and risks" (Witcher \& Chau, 2010, p. 91). 
This current study is focused on three of the factors in the PESTEL framework in the intercollegiate athletics environment: the economic, sociocultural, and legal factors. The widening revenue gap among FBS institutions is the focus for the economic factor. The focus of the sociocultural factor is the amount of value produced by student-athletes versus the value of an athletic scholarship. Finally, the current litigation involving the NCAA and its member institutions, including the O'Bannon lawsuit and others, represents the legal factor.

\section{Economic Factors}

There is a dynamic that exists with NCAA Division I FBS institutions at it relates to spending and competition. Cheslock and Knight (2015) presented a conceptual framework to describe this dynamic and the resulting dichotomy between programs with the revenue to drive expenses and those that are just trying to keep up. Their framework consisted of diverging revenues, cascading expenditures, and ensuing subsidies. They pointed out that the nature of the financial challenges is complicated due to the diversity among the programs. There are institutions with enrollments as high as 60,000 students operating athletic departments with budgets over $\$ 100$ million competing alongside institutions with enrollments as low as 4,000 students and operating athletic departments with budgets under $\$ 30$ million.

Matheson, O'Connor, and Herberger (2012) examined the revenues and expenses of major universities' athletic programs to determine the extent to which athletic programs either generate revenues or impose costs upon the host institution. They found that only 15 of 166 NCAA Division I athletic programs were profitable without receiving subsidies from the institution, with an average shortfall of \$6 million. This finding reinforces the third aspect of the Cheslock and Knight (2015) framework, further highlighting the idea that a small number of athletic programs drive expenses higher and the majority of programs are finding it difficult to generate the revenue necessary to offset these higher expenses.

\section{Sociocultural Factors}

For this current study, the sociocultural sector was primarily centered on student-athletes and their well-being. Football and men's basketball are the only two revenue-generating sports for colleges and universities. As such, based on the large amount of revenue being generated for their universities and the limit that is placed on the athletic scholarship, some scholars and journalists hold the perception that student-athletes are exploited (Berri, 2014; Branch, 2011). These scholars and journalists say this because the value of a full scholarship that is allowed to a student-athlete is capped at the amount of money it takes to pay tuition, books, fees, room, board, and cost of attendance (NCAA, 2018). "The 'cost of attendance' is an amount calculated by an institutional financial aid office, using federal regulations, that includes the total cost of tuition and fees, room and board, books and supplies, transportation, and other expenses related to attendance at the institution" (NCAA, 2018, p. 200).

Van Rheenen (2013) examined the issue of student-athlete exploitation through the economic concepts of surplus value and marginal revenue product. He explained that a surplus value is created for FBS football and men's basketball student-athletes when their labor is commodified when they receive compensation in the form of a scholarship in exchange for the 
value created by their labor. While the NCAA still defines student-athletes as amateurs, it has no bearing on commodification as long as the people who pay to watch the games still receive the material object; in this case the performance of the student-athlete.

Empirical studies have been conducted that estimated that the marginal revenue product for FBS football and men's basketball student-athletes can reach $\$ 1$ million for their respective institutions (Brown, 1994; 2011). Values at those levels indicate that some football and men's basketball student-athletes are indeed economically exploited, as scholarship values are limited to tuition, books, fees, room, board, and cost of attendance. In intercollegiate athletics, this exploitation is used to benefit other athletes in non-revenue producing sports, as well as salaries for coaches, administrators, and facility construction (Van Rheenen, 2013).

\section{Legal Factors}

In addition to the previous cases discussed, over the last decade there have been numerous lawsuits brought against the NCAA and its member institutions by student-athletes (LeRoy, 2015). These lawsuits have been precipitated by damages stemming from the limiting of scholarship value, failing to pay all educational costs, using student-athletes' NIL without compensation or consent, providing better medical care including damages for concussion injuries, and limiting multiyear scholarships. The following is a review of some of those cases and their outcomes that comprise the NCAA's external environment.

In the White v. National Collegiate Athletic Association (2006) case, student-athletes from Stanford University, UCLA, University of San Francisco, and the University of Texas at El Paso argued that the members of the NCAA had unlawfully agreed to deny student-athletes a share of the revenue they helped generate. Furthermore, they claimed that without an unlawful agreement, members of the NCAA would compete against each other for talent, which in turn would increase the value of a scholarship. The case was settled on the conditions that the NCAA would make available $\$ 218$ million to member institutions for use in a student-athlete opportunity fund to be used by student-athletes who demonstrated academic or financial needs. Additionally, the NCAA was to make available $\$ 10$ million over a three-year period to be distributed to the class members who could then apply for the money for career development services and continued education expenses.

In 2008, Andy Oliver filed a lawsuit against the NCAA and sought a declaratory judgment finding that NCAA Bylaws Section 12.3.2.1 was unenforceable, arbitrary, and capricious (Dennie, 2012; Oliver v. Baratta, 2008). Oliver was drafted to play baseball professionally out of high school. He retained an advisor to assist with a decision to accept a $\$ 390,000$ offer to play professionally or go to Oklahoma State University; he eventually chose to go to college. Once arriving at Oklahoma State University, he fired his advisor, who told the NCAA about his former arrangement with Oliver, thus sparking an investigation by the NCAA. The investigation was aimed at finding out if Oliver had violated NCAA Bylaws Section 12.3.1 and 12.3.2.1. Bylaw 12.3.1 states that an individual is ineligible for participation in an intercollegiate sport if they have hired an agent for the purposes of representing their athletic interests and Bylaw 12.3.2.1 states that a lawyer could not be present during contract discussions with a professional sports organization (NCAA, 2018). The investigation concluded that Oliver had violated these bylaws 
and he was suspended indefinitely (Dennie, 2012). His 2008 lawsuit included an injunction on his suspension.

The judge in the case granted Oliver relief, stating that the student-athlete was a third party beneficiary of the NCAA's agreement with Oklahoma State University. Furthermore, the judge chastised the NCAA for the bylaw, saying it was unenforceable and allowed for the exploitation of student-athletes, and struck down the bylaw. However, Oliver and the NCAA settled the case, with Oliver receiving $\$ 750,000$ and agreeing to vacate the judgment, which allowed the bylaw to stand and is still in the NCAA manual today (Dennie, 2012; NCAA, 2018; Oliver v. Baratta, 2008).

In 2009, Sam Keller, a former football student-athlete at Arizona State University and the University of Nebraska, filed a lawsuit against the NCAA, Electronic Arts (EA), and the Collegiate Licensing Company (CLC). He alleged these defendants of blatantly and unlawfully misappropriating his and other student-athlete's likenesses in video games produced by EA. Keller illustrated the similarities between the student-athletes in the game, i.e., avatars, and their real life counterparts by showing that each avatar and the real life counterpart shared the same uniform number, height, weight, skin color, and other physical characteristics (Dennie, 2012; Keller v. Electronic Arts, Inc., 2009).

The Keller case was certified as a class-action lawsuit and, combined with the O'Bannon case, proceeded on the basis that EA, CLC, and the NCAA violated rights of both publicity and antitrust laws. The case was settled regarding the rights of publicity with EA and CLC for $\$ 40$ million and with the NCAA for \$20 million (Keller v. Electronic Arts, Inc., 2009). However, that left the issue of antitrust violations to be contended with in the O'Bannon v. NCAA case.

Altogether, the Alston, Jenkins, and O'Bannon cases demonstrate the willingness of current and former student-athletes to take to the courts their grievances with the current NCAA system. This demonstration shows the need to examine the legal sector of the intercollegiate athletics environment. Furthermore, it provides the basis for forecasting what will take place in the legal sector over the next five to seven years.

\section{Purpose of Study}

The purpose of the current study was to assess the changes taking place in the environment in which intercollegiate athletics operates and to forecast the consequences of those changes over the next five to seven years. Specifically, the economic, sociocultural, and legal sectors of the intercollegiate athletics environment were the focus of this study. Having this information will allow the NCAA and its member institutions to evaluate the proper stakeholder management approach, understand the salience of the different stakeholder groups, and assess whether or not those levels of salience align with the mission of the organizations (Chelladurai, Inglis, \& Danylchuk, 1984; Putler \& Wolfe, 1999; Trail \& Chelladurai, 2000). Through effective management of stakeholder relationships, intercollegiate athletic departments can potentially increase their levels of success (Covell, 2005; Wolfe, Hoeber, \& Babiak, 2002; Wolfe \& Putler, 2002). 
Forecasting is required to predict the needs of an organization and decide what actions must be taken ahead of time to fulfil those needs (Makridakis, 1990). In their study on forecasting future issues in collegiate athletics, Branch and Crow (1994) noted that, "the ability to forecast and predict the course of significant events may well distinguish the future success of athletic organizations" (p. 14). Being prepared with a strategy to deal with changes to the environment ensures the best chances at success for the NCAA and its member institutions. With that aim in mind, the following research questions guided the course of this study.

\section{Research Questions}

1. What issues will arise and what level of impact will they have over the next five to seven years as a result of the legislative autonomy granted to the Power 5 conferences in the:

a. Economic sector of the FBS athletics environment?

b. Sociocultural sector of the FBS athletics environment?

c. Legal sector of the FBS athletics environment?

2. What issues will arise and what level of impact will they have over the next five to seven years as a result of the legal actions targeting the NCAA and its member institutions in the:

a. Economic sector of the FBS athletics environment?

b. Sociocultural sector of the FBS athletics environment?

c. Legal sector of the FBS athletics environment?

\section{Methodology}

The design of this study utilized a mixed method approach employing the Delphi technique as both the research design and data collection method. The purpose of using a Delphi technique is "to obtain the most reliable consensus of opinion of a group of experts" (Dalkey \& Helmer, 1963, p. 458). There are four main characteristics involved in a Delphi technique: (a) anonymity in the process, (b) controlled feedback, (c) iteration, and (d) statistical aggregation of group response (Gnatzy, Warth, von der Gracht, \& Darkow, 2011). The absence of any of these elements undermines the results obtained from the study. Conversely, the proper execution of each element can help to ensure the credibility of the findings of the study as a whole (Yousuf, 2007).

Anonymity is an essential characteristic of the Delphi technique, as it allows for a debate among the group of experts while reducing the possible effect of a socially dominant member of the group (Dalkey, 1967). This is critical in two ways. First, it allows the experts to share their opinions, even extreme ones, without concern for being ostracized. Second, it lends itself to higher response rates (von der Gracht, 2012). Anonymity is accomplished through the use of questionnaires, which allows panel members to express their opinions privately and is based on merit alone (Rowe \& Wright, 1999). Furthermore, anonymity allows people with conflicting personalities to work productively together (Delbecq, Van de Ven, \& Gustafson, 1975).

Anonymity for this study was achieved through the use of the secure, online survey tool Qualtrics. With the use of Qualtrics, the panel of experts were able to complete each round of 
surveys without having to interact with other members of the panel. Additionally, the only identifying characteristics that were asked of respondents were conference affiliation, gender, and race.

The second characteristic involved with the Delphi technique is controlled feedback. This feedback, provided by the researcher, informs the panel members of the opinions of their anonymous colleagues (Rowe \& Wright, 1999). The control of the feedback by the researcher allows for the elimination of non-relevant conversation that can take place during a face-to-face group meeting. Additionally, it allows the researcher to ensure that the focus remains on the subject of interest.

The controlled feedback took place between the multiple iterations or rounds, which is the third requirement of the Delphi technique. The purpose of multiple iterations is to determine consensus of opinion among the panel of experts on each topic (Hsu \& Sandford, 2007). Iteration, combined with anonymity, also allows the experts a chance to change their opinion without losing face with the other experts (Rowe \& Wright, 2001). Most literature says that three iterations are enough and that more than that provides diminishing returns (Davidson, 2013; Ludwig, 1997; Yousuf, 2007). In accordance with these findings, three rounds were used in the current study. The first round (Appendix A) consisted of open-ended questions formulated from the literature review and research questions, as suggested by Davidson (2013). Additionally, four experts not serving on the Delphi panel reviewed the first round questionnaires for conciseness and coherence. After the first round, the second and third rounds consisted of a questionnaire rating the likelihood and impact of consequences gleaned from the first round. The responses from the group of experts were statistically aggregated to form one group opinion.

Statistical aggregation is the fourth characteristic of the Delphi technique. Central tendency measures are the main statistics used in aggregating responses (Rowe \& Wright, 2001). When using Likert scales, medians are generally preferred to the mean, as medians are not skewed by extreme values (Hsu \& Sandford, 2007). These medians are reported back to the group between each iteration of the study as the controlled feedback. This type of feedback is what facilitates the convergence of opinion to consensus. Consensus is defined by the researcher prior to the study and is generally seen as a certain percentage of votes from the experts that fall within a prescribed range (Hsu \& Sandford, 2007).

\section{Sample and Participants}

For the purposes of this study, the focus for the expert panel was on senior level administrators of intercollegiate athletic departments. This group was chosen as the focus because of its day-to-day involvement with the enterprise from a decision-making standpoint. While the author acknowledges the involvement of many other stakeholders in the day-to-day business of intercollegiate athletics, the Delphi technique requires experts and this group had the most expertise based on their positions, perspectives, and experiences.

For the current study, experts were identified as NCAA Division I FBS directors of athletics and associate athletic directors with at least five years of experience in those positions. People in these positions were chosen for the depth of intercollegiate athletics knowledge 
necessary to attain their positions (Wright, Eagleman, \& Pedersen, 2011). Furthermore, people holding these positions are considered top management decision-makers who are involved with organizational strategic planning (Hsu \& Sandford; 2007; Wolf \& Floyd, 2013) and would be more invested in the results of the study. Additionally, to give a greater breadth of experience to the group, panel members had to have worked at a minimum of two FBS institutions to be selected as a participant. Finally, to ensure that as many groups were represented as possible, the panel participants consisted of male and female administrators, Power 5 and Group of 5 representation, and People of Color and White administrators.

There is no consensus on the number of people that should comprise an expert panel for a study using the Delphi technique, as it is generally dependent on the study itself (Hsu \& Sandford, 2007; Yousuf, 2007). However, several studies suggest between five and 30 (Adler \& Ziglio, 1996; Dalkey \& Helmer, 1963; Delbecq et al., 1975; Rowe \& Wright, 2001). For the current study, a purposive sample of 31 experts was identified based on the aforementioned criteria, 12 of whom participated in the study. A purposive sample is necessary due to the necessity of expert opinion (Skulmoski, Hartman, \& Krahn, 2007). Furthermore, this study employed both the maximum variation and criterion sampling approaches (Suri, 2011).

This group of people was chosen for the expert panel because they had the most expertise to answer the research questions. Moreover, their daily job duties require interaction with a wide range of stakeholders including student-athletes, faculty, donors, community members, television partners, sponsors, and members of the media. Interacting with these stakeholders gives the panel the type of insight needed to forecast future issues and how those issues will impact stakeholder relationship management. Finally, as participant dropout is a potential limitation of the Delphi technique, the backgrounds of these participants made them more likely to be invested in the results, thus increasing the chances of participation through all three rounds of the study.

\section{Data Coding}

In order to analyze the data obtained from the open-ended questionnaire in the first round, a content analysis was performed. Content analysis is a "research method for the subjective interpretation of the content of text data through the systematic classification process of coding and identifying themes" (Hsieh \& Shannon, 2005, p. 1278). The text data was in the form of responses to the first round questionnaire. One of the advantages of content analysis as a qualitative methodology is the ability to gain information directly from the study participants without the influence of previously established themes (Hsieh \& Shannon, 2005).

The first step in a content analysis is to carefully read through all the responses. Then, the responses are read again in order to develop initial key concepts and themes (Cerritos College, 2016; Hsieh \& Shannon, 2005). As the themes and key concepts are developed, they are labelled, or coded, in order to group responses for analysis.

Coding is a way of organizing the data into categories to allow for interpretation (Gibbs, 2007; Saldaña, 2016). For this study, three steps were taken in order to code the responses as suggested by Auerbach and Silverstein (2003). First, the relevant text was identified during the initial phase of the content analysis. Following the identification of the relevant text, repeating 
ideas were highlighted. The repeating ideas were then organized into categories supported by individual issues. Once the issues were categorized, an instrument was created to facilitate the rating of these issues by the expert panel in terms of likelihood and impact.

Upon the creation of the instrument, the expert panel was contacted requesting their review of the questionnaire for the second round of the study. They were asked to evaluate each item on the likelihood of occurring in the next five to seven years and its perceived impact. As has been suggested in other studies (Franklin \& Hart, 2007; Rådestad et al., 2013), both the likelihood and impact evaluations were done on a scale of one to five with one being low and five being high.

Once all the responses were collected, the results were aggregated and shared with the panel. For the third round, the panelists were asked if they wanted to revise their judgement on any of the items where they were outside of the consensus and, if not, to specify why they felt content with their current evaluation.

As stated earlier, central tendency measures (i.e., mean, median, and mode) are the main statistics used in the analysis of responses in a Delphi study. Additionally, standard deviation and interquartile range are often used to measure the level of dispersion (Rowe \& Wright, 1999). The literature suggests that medians are the best of the central tendency measures to use with Likert scale data, as they are not skewed by outliers (von der Gracht, 2012). Consensus for this study was defined as a median score above three for each item (Hsu \& Sanford, 2007).

\section{Data Analysis}

The initial questionnaire was sent to 31 athletic directors and associate athletic directors representing all 10 NCAA FBS conferences. Of the initial requests, 12 participants (see Table 1) responded with answers to the first round questionnaire. Among the 12 participants were four directors of athletics, eight associate athletic directors, seven who self-identified as Whites, three African Americans, two Hispanics, nine males, three females, 10 representatives from the Power 5 conferences, and two representatives from the Group of 5 conferences. All of the respondents had 11 or more years of experience working in intercollegiate athletics. 
Table 1

\section{Participant Demographics}

\begin{tabular}{ccccc}
\hline Participant & Gender & Race & Conference Affiliation & Position \\
\hline 1 & Female & White & Power 5 & Director of Athletics \\
2 & Male & African-American & Power 5 & Director of Athletics \\
3 & Female & White & Power 5 & Deputy Director of Athletics \\
4 & Male & African-American & Power 5 & Executive Associate Director of Athletics \\
5 & Female & White & Power 5 & Associate Director of Athletics \\
6 & Male & African-American & Group of 5 & Deputy Director of Athletics \\
7 & Male & White & Power 5 & Associate Director of Athletics \\
8 & Male & Hispanic & Power 5 & Senior Associate Director of Athletics \\
9 & Male & White & Power 5 & Director of Athletics \\
10 & Male & White & Power 5 & Associate Director of Athletics \\
11 & Male & Hispanic & Group of 5 & Director of Athletics \\
12 & Male & White & Power 5 & Associate Director of Athletics \\
\hline
\end{tabular}

The questionnaire (Appendix A) consisted of 16 questions, with the first five questions pertaining to demographic information and the following 11 open-ended questions related to the research questions. The first of these 11 questions was meant to obtain respondents' general thoughts on what futures issues for which NCAA Division I FBS athletic department administrators would need to be prepared. The next five questions were aimed at deriving future issues related to the granting of autonomy to the Power 5 conferences. The final five questions were asked in order to obtain the expert panel's prediction of issues related to the current legal disputes involving the NCAA and its member institutions.

As described earlier, a content analysis was performed on the respondents' answers to the 11 open-ended questions and 20 issues were revealed (see Table 2). There were seven economic issues, 10 sociocultural issues, and three legal issues. These 20 issues were then used as the basis of the instrument that was sent to the expert panel for the second round of the study. 
Table 2

Issues Generated from First Round of Data Collection

\begin{tabular}{|c|c|}
\hline Category & Issue \\
\hline Economic & $\begin{array}{l}\text { Expenses will increase at a faster rate than revenues for FBS athletic } \\
\text { programs over the five to seven years. }\end{array}$ \\
\hline Economic & $\begin{array}{l}\text { The number of sports required for FBS membership will be lowered over } \\
\text { the next five to seven years. }\end{array}$ \\
\hline Economic & $\begin{array}{l}\text { Television revenue will decrease for FBS athletic programs over the next } \\
\text { five to seven years. }\end{array}$ \\
\hline Economic & $\begin{array}{l}\text { Ticket revenue will decrease for FBS athletic programs over the next five } \\
\text { to seven years. }\end{array}$ \\
\hline Economic & $\begin{array}{l}\text { The revenue gap between the Power } 5 \text { conferences and the Group of } 5 \\
\text { conferences will widen over the next five to seven years. }\end{array}$ \\
\hline Economic & $\begin{array}{l}\text { Student-athletes transferring from Group of } 5 \text { conferences to Power } 5 \\
\text { conferences will increase over the next five to seven years. }\end{array}$ \\
\hline Economic & $\begin{array}{l}\text { Further FBS conference realignment will take place over the next five to } \\
\text { seven years. }\end{array}$ \\
\hline Legal & $\begin{array}{l}\text { There will be an increase in lawsuits from former FBS student-athletes } \\
\text { brought against the NCAA, FBS conferences, and FBS institutions over } \\
\text { the next five to seven years. }\end{array}$ \\
\hline Legal & $\begin{array}{l}\text { There will be an increase in lawsuits from current FBS student-athletes } \\
\text { brought against the NCAA, FBS conferences, and FBS institutions over } \\
\text { the next five to seven years. }\end{array}$ \\
\hline Legal & $\begin{array}{l}\text { There will be an increase in favorable rulings for plaintiffs in lawsuits } \\
\text { brought by current and former FBS student-athletes against the NCAA, } \\
\text { FBS conferences, and FBS institutions over the next five to seven years. }\end{array}$ \\
\hline
\end{tabular}


Table 2 (continued)

\begin{tabular}{ll}
\hline Category & Issue \\
\hline Sociocultural & $\begin{array}{l}\text { FBS student-athletes will begin to be allowed to receive compensation for } \\
\text { use of their name, image, and likeness from external entities (e.g. } \\
\text { sponsors, booster clubs) over the next five to seven years. }\end{array}$ \\
Sociocultural & $\begin{array}{l}\text { FBS student-athletes will be required to spend less time on athletics over } \\
\text { the next five to seven years. }\end{array}$ \\
Sociocultural & $\begin{array}{l}\text { There will be an increase in focus on student-athlete well-being over the } \\
\text { next five to seven years. }\end{array}$ \\
& $\begin{array}{l}\text { Academic eligibility requirements will increase for FBS student-athletes } \\
\text { over the next five to years. }\end{array}$
\end{tabular}

Sociocultural The NCAA will receive an antitrust exemption in the next five to seven years.

Sociocultural FBS athletic programs will devote a larger percentage of revenue to student-athlete well-being initiatives over the next five to seven years.

Sociocultural

FBS athletic programs will increase the amount of a full athletic scholarship beyond cost of attendance over the next five to seven years.

Sociocultural FBS athletic programs will remove the limit on the value of an athletic scholarship over the next five to seven years.

Sociocultural FBS student-athletes will not be required to be full-time students to participate in athletics in the next five to seven years.

Sociocultural FBS student-athletes will be given the choice to receive a scholarship and attend classes or be hired as an employee strictly for athletics in the next five to seven years. 
For the second round of the study, the participants were asked to rate each of the 20 issues on the likelihood of occurring and level of impact if the issue were to occur. A scale of one to five was used, with one being low and five being high. After the participants rated the issues for the second round, eight of the issues reached the consensus criteria of a median score above three on likelihood of occurring. There were 14 issues that reached the consensus criteria of a median score above three on level of impact. There were a total of seven issues that reached consensus on both likelihood of occurring and level of impact.

Of the eight issues that reached consensus on likelihood of occurring, four were in the economic category, three were in the sociocultural category, and one was in the legal category. Of the 14 issues that reached consensus on level of impact, all seven economic issues reached consensus, five of the sociocultural issues reached consensus, and two of the legal issues reached consensus. For the issues that reached consensus on both likelihood of occurring and level of impact, four of the issues were economic, two were sociocultural, and one was legal.

The third round of the study involved sending the expert panel the aggregated results from the second round. Each panel member was alerted to the issues for which their rating fell outside of the consensus of the group on either likelihood to occur or level of impact. They were then asked if they wanted to change their score and, if not, to explain why they continued to disagree with the group. After the three rounds were completed, there was consensus on the likelihood of eight issues occurring, consensus on 14 issues having a high level of impact if they were to occur, and consensus was reached on both likelihood to occur and level of impact for seven issues (see Table 3). 
Table 3

Issues On Which the Panel Reached Consensus for Both Likelihood and Impact

\begin{tabular}{|c|c|c|}
\hline Category & Medians & Issues \\
\hline Economic & 5-L, 4-I & $\begin{array}{l}\text { Expenses will increase at a faster rate than revenues for } \\
\text { FBS athletic programs over the five to seven years. }\end{array}$ \\
\hline Economic & 4-L, 4-I & $\begin{array}{l}\text { Ticket revenue will decrease for FBS athletic programs } \\
\text { over the next five to seven years. }\end{array}$ \\
\hline Economic & 5-L, 4-I & $\begin{array}{l}\text { The revenue gap between the Power } 5 \text { conferences and the } \\
\text { Group of } 5 \text { conferences will widen over the next five to } \\
\text { seven years. }\end{array}$ \\
\hline Economic & 3.5-L, 4-I & $\begin{array}{l}\text { Student-athletes transferring from Group of } 5 \text { conferences } \\
\text { to Power } 5 \text { conferences will increase over the next five to } \\
\text { seven years. }\end{array}$ \\
\hline Legal & 4-L, 4-I & $\begin{array}{l}\text { There will be an increase in lawsuits from former FBS } \\
\text { student-athletes brought against the NCAA, FBS } \\
\text { conferences, and FBS institutions over the next five to } \\
\text { seven years. }\end{array}$ \\
\hline Sociocultural & $5-\mathrm{L}, 4.5-\mathrm{I}$ & $\begin{array}{l}\text { There will be an increase in focus on student-athlete well- } \\
\text { being over the next five to seven years. }\end{array}$ \\
\hline Sociocultural & 4-L, 4-I & $\begin{array}{l}\text { FBS athletic programs will devote a larger percentage of } \\
\text { revenue to student-athlete well-being initiatives over the } \\
\text { next five to seven years. }\end{array}$ \\
\hline
\end{tabular}

$\mathrm{L}=$ panels' rating of the likelihood of the issue occuring

I=panel's rating of the level of impact of the issue if it were to occur 


\section{Results and Discussion}

The expert panel identified 20 total future issues based on their responses to the open-ended questionnaire used in the first round of the study. The issues were categorized as relating to either the economic, sociocultural, or legal sector of the intercollegiate athletics environment. While some issues could be categorized into multiple categories, each one had a dominant feature related to its final categorization for the purposes of this study. Descriptive statistics were run using SPSS 24 to obtain the median score for each issue on likelihood to occur and level of impact. Among the 20 issues, the expert panel reached consensus on likelihood to occur for eight of the issues. The panel reached consensus on level of impact for 14 of the issues. Finally, there were a total of seven issues that reached consensus on both likelihood to occur and level of impact.

\section{Economic Issues}

Economic issues provide a significant challenge to NCAA Division I FBS athletics. The expert panel identified seven economic issues and came to a consensus that four of the seven are likely to occur. Even more telling is that the panel came to a consensus that all seven items would have a high level of impact if they were to occur. Based on the responses to the first-round questionnaire, the economic issues identified primarily related to the granting of autonomy to the Power 5 conferences.

There were two economic issues that had a median score of 5 on likelihood to occur. The first of these issues was:

"Expenses will increase at a faster rate than revenues for FBS athletic programs over the next five to seven years."

“...rising cost of expenses."

“...stagnant revenue streams."

This forecast is consistent with the conceptual framework put forth by Cheslock and Knight (2015). Their framework presented ideas of diverging revenues and cascading expenditures. When these two concepts are combined, the result will be expenses increasing at a faster rate than revenues for most programs. This issue also had consensus on level of impact if it were to occur with a median score of 4 . It is logical that this expert panel would find that this issue would have a significant impact, as they are generally the personnel tasked with finding sources of revenue to cover the increasing expenses, managing the budgets, and working on cost containment.

The second economic issue to receive a median rating of 5 on likelihood to occur was:

"The revenue gap between the Power 5 conferences and the Group of 5 conferences will widen over the next five to seven years." 
"...the widening financial gap between the Autonomous 5 (Power 5) and the Group of 5."

“...broadening the gap [between Group of 5 and Power 5 conferences].”

This forecast supports the thinking of Dunn (2013) and Matheson et al. (2012). The largest reason for the current gap is the discrepancy between the television revenue brought in by the Power 5 conferences and the Group of 5 conferences (Hobson \& Rich, 2015; Zimbalist, 2013). Based on their responses and ratings, the expert panel predicted that Power 5 conference television revenue will continue to far outpace Group of 5 television revenue.

The second economic issue also reached consensus on level of impact if it were to occur with a median rating of 4 . The Group of 5 programs will feel most of the impact as they continue to try and keep up spending with the Power 5 programs despite the lack of revenues (Dodd, 2016). However, this could also affect Power 5 programs in the future because Group of 5 programs could decide to stop competing in the same subdivision of the NCAA. This would eliminate half of the subdivision, making it difficult for Power 5 programs to find enough games to fill out the schedules of the various sports they sponsor.

Another issue reaching consensus on likelihood to occur was:

"Ticket revenue will decrease for FBS athletic programs over the next five to seven years."

"The demand for season tickets will decrease."

“...challenge to maintain attendance levels at events."

It received a median score of 4 from the panel. This issue coincides with the widening revenue gap as they are both related to television and the revenue derived from television contracts. The increased exposure of college athletics on television has had the consequence of a decline in stadium and arena attendance for college athletic programs (Rishe, 2015). The ubiquity of college sports on television, the increased quality of televisions being produced, and the increase in costs associated with attending events in person has made it less time-consuming, more comfortable, and cheaper for fans to watch their favorite teams from home. The expert panel forecasted this trend to continue.

While television contracts provide a large amount of revenue to FBS programs, ticket revenue is still a significant source of revenue for most programs and as such, this issue also reached consensus on level of impact if it were to occur. The panel rated this issue with a median of 4 . The impact of less people attending events in person is not only felt by athletic departments through loss of ticket revenue, it is also felt in the potential loss of donors. Athletic departments often require donations to ticket purchases (Wolverton \& Kambhampati, 2015) and if less people are attending events, then it is possible that less people will be donating to the program. However, the donations related to tickets could also be impacted by the excise tax on sports and entertainment, which removes the tax deductibility of donations required for ticket purchases. 
The final economic issue to receive consensus from the panel on likelihood to occur, with a median score of 3.5 , was:

"Student-athletes transferring from Group of 5 conferences to Power 5 conferences will increase over the next five to seven years."

"More of the talent will gravitate toward Power 5 institutions."

"There will be an increasing talent divide between Power 5 and Group of 5."

This issue relates directly to the widening revenue gap between the Power 5 conferences and the Group of 5 conferences. As the Power 5 programs increase their revenue and corresponding expenditures on facilities, coaches, and support staff, Group of 5 programs will struggle to keep up. The result, as forecasted by the expert panel, will lead to an increase in student-athlete transfers from Group of 5 programs to Power 5 programs.

This transferring issue also reached consensus on level of impact with a median score of 4 . The general thought is that an even larger percentage of the most athletically talented studentathletes will end up at Power 5 programs, consequently increasing victories and drawing more interest from fans. This increased interest will result in more revenue from television, ticket sales, and sponsorships. Additionally, it causes the Group of 5 programs to increase recruiting expenses in order to replace the transferring athletes. It also relates to the previous Cheslock and Knight (2015) concept of cascading expenditures. As Group of 5 programs try to retain their talented student-athletes, their institutions will likely resort to increasing student fees (Denhart, Ridpath, \& Vedder, 2011; Morton, 2017) in order spend more money on facilities, coaches, and support staff to do so.

The expert panel clearly felt that economic issues would be critical to the operation of intercollegiate athletics at the NCAA Division I FBS level. They reached consensus on four of the seven issues on likelihood to occur and on all seven issues on level of impact. These results tell us that as intercollegiate athletic administrators prepare for the next five to seven years, they should focus on how their program will generate revenue, reduce expenses, and understand possible alternatives for both if their expectations differ from actual results.

\section{Sociocultural Issues}

The second environmental sector examined for this study was the sociocultural sector. The first round of the study revealed 10 sociocultural issues, all of which were related to the well-being of student-athletes. The expert panel reached consensus on three of the issues on likelihood to occur and five of the issues on level of impact.

There was one sociocultural issue that reached consensus on likelihood to occur with a median rating of 5: 
"There will be an increase in focus on student-athlete well-being over the next five to seven years."

“...enhance support services and experiences of student-athletes."

"Student-athletes will reap increased benefits as they pertain to their athletic participation."

Arguments have been made that certain student-athletes are exploited by their institutions (Brown, 2011; Van Rheenen, 2013). Additionally, it has been found that some student-athletes feel they are exploited (Van Rheenen, 2011). This particular forecast is significant in that this group of experts suggested that there will be an attempt by FBS conferences and institutions to lessen the perceived exploitation. This would be an extension of current efforts that are exemplified by the cost of attendance stipend (Berkowitz, 2015), multi-year scholarships (Solomon, 2014), and increased meal allowances (Hosick, 2014). Not surprisingly, this issue received a median score of 4.5 from the expert panel on level of impact. In order to facilitate this increased focus on studentathlete well-being, institutions will have to shift the way they operate in order to allocate resources to achieve this goal. This shift relates directly to the next issue forecasted by the panel.

The panel forecasted that:

"FBS athletic programs will devote a larger percentage of revenue to student-athlete well-being initiatives over the next five to seven years," with a median rating of 4 on likelihood to occur.

“...provide more resources to student-athletes."

“...allow for expenditures to support and enhance the student-athlete experience."

With this prediction, the panel advanced the first reported sociocultural issue by revealing that one of the ways institutions will increase their focus on student-athletes is to allocate more revenue to initiatives and programs that positively affect student-athletes' experiences on campus. This forecast is a logical one when considered against the backdrop of Power 5 autonomy. Part of the impetus behind the Power 5 conferences asking for autonomy was to be able to spend more money on student-athlete well-being (Wolverton, 2014). It then follows, based on the Cheslock and Knight (2015) framework, that as the higher resourced Power 5 programs spend more on studentathletes, the Group of 5 programs will attempt to do the same in order to keep up with their FBS peers. Because of the financial repercussions of this shift in philosophy, the expert panel reached consensus on this issue for level of impact with a median rating of 4 . This is consistent with how they rated the economic issues on level of impact, reaffirming the importance of revenue generation and allocation for athletic administrators in FBS athletic programs.

The final sociocultural issue the panel reached consensus on likelihood to occur, with a median score of 4.5, was: 
"FBS student-athletes will be required to spend less time on athletics over the next five to seven years."

"...define time demands and limit countable hours."

"Time balance issues with student-athletes will remain at the forefront."

This is a logical conclusion reached by the panel, as there has already been legislation adopted by the NCAA to require more days off for Division I student-athletes (Hosick, 2017). The new legislation is meant to create more days off that are truly free of time commitments, such as media or community service commitments (New, 2017). This legislation can be seen as an attempt to mitigate the perception that student-athletes are being exploited by the institutions they represent on the playing field.

The new legislation is certainly a benefit to current and future student-athletes, as it allows them more time to spend on their studies, recreational activities, and other interests. What remains to be seen is whether more time requirement reductions will take place in reaction to a continued perception of exploitation and/or litigation brought on behalf of current and/or former studentathletes. Regardless of how much more reduction in required time is legislated, the panel did not foresee this issue as having a significant level of impact, as it received a median score of 2 for that aspect of the forecast. However, one way in which this issue could have a significant impact is if there were a reduction of either lengths of playing seasons or number of contests played. This is particularly true in the sports of football and men's basketball. These two sports drive most of the revenue generated by athletic departments (Zimbalist, 2013) and a reduction in the number of televised contests could potentially drive down the rights fees offered by television partners. Additionally, fewer contests would result in a loss of ticket revenue. This panel has demonstrated, with their ratings of the level of impact for the economic issues, that revenue generation is a critical area of concern for future planning.

\section{Legal Issues}

The most significant forecast made by the expert panel in the legal sector was:

"There will be an increase in lawsuits from former FBS student-athletes brought against the NCAA, FBS conferences, and FBS institutions over the next five to seven years."

“...conferences will have to deal with more lawsuits."

"The number and type of lawsuits will certainly significantly increase."

This issue received a median rating of 4 from the panel. In the past, significant change in intercollegiate athletics has generally come from either the courts via current and former studentathletes or the government (Smith, 2011). This is important to note, as this group of experts forecasted more legal action will be taken by former student-athletes. If more lawsuits are brought against the NCAA and its member institutions, it stands to reason that the current structure of operation for FBS athletics could undergo significant change. One can point to Title IX as an 
example of how both the government and courts have fundamentally altered the way intercollegiate athletics operates (Smith, 2011). With that knowledge as a backdrop, it should come as no surprise that the expert panel also reached consensus, with a median rating of 4 , on level of impact if this issue were to occur.

The expert panel forecasted continued legal challenges to the NCAA, FBS conferences, and FBS institutions over the next five to seven years. By reaching consensus on level of impact for two of the three legal issues, they expected the outcomes of these legal challenges to have a significant impact on the operation of intercollegiate athletics. Potential consequences included an increased voice for student-athletes related to legislation, a change in the scholarship limit, and the increased allocation of resources toward student-athletes.

\section{Recommendations}

The expert panel in the current research investigation provided a forecast that athletic directors and their staffs can use to aid in their strategic planning. This study focused on three areas of the NCAA Division I FBS environment and the panel generated issues for consideration in all three. Based on the experts' ratings, it is clear that economic issues are a high priority for this group of administrators and should be for others, as well.

By forecasting a faster pace of increase for expenses compared to revenues, this panel has suggested that the search for new revenue sources will continue to be important. This is especially true for the programs in the Group of 5 conferences. This is because the group of experts also forecasted a widening revenue gap between the Power 5 and Group of 5 conferences. When combined, these two predictions and the forecasted decrease in ticket revenue should prompt the athletic directors of these programs to search for ways to take advantage of new technologies and potential changes to the marketplace. For instance, as more and more people have moved away from subscribing to cable television and are obtaining their programming from alternate sources (Baccarne, Evens, \& Schuurman, 2013), it may be possible for a conference to create its own content delivery network that does not rely on traditional television networks for distribution. While some conferences already have a digital network (e.g., ACC, SEC), this could expand on that model by taking all of a conference's inventory, including football and men's basketball, and distributing it solely through this new network without partnering with traditional broadcast networks. This network would have to take advantage of emerging technologies and shifting attitudes towards content consumption in order to increase revenues enough to forego the relationships with the traditional broadcast networks. It will require innovative thinking, along with recognition of current trends, in order for programs to generate the revenue necessary to remain competitive over the next five to seven years.

In order for athletic departments to handle the economic issues forecasted in this study, it will be important to engage with two stakeholder groups, specifically donors and media companies, e.g., ESPN and FOX. Relationships between these groups and athletic departments will have to be managed in a way that generates enough revenue to be effective. This is especially true as federal and state funding for higher education continue to decrease (Mitchell, Leachman, \& Masterson, 2016), requiring alternative sources of revenue for colleges and universities in general. 
Athletic fundraising accounted for $\$ 1.26$ billion in 2014 (Wolverton \& Kambhampati, 2015). This amount was the highest total in 10 years and the only way athletic departments were able to raise that amount of money was by properly managing their relationships with the donor stakeholder group. This relationship management will only increase in importance based on the economic issues forecasted by the expert panel, along with the change in the law that no longer allows money given in exchange for tickets to be considered as a tax deductible donation.

Television contracts are also responsible for contributing large amounts of revenue to FBS athletic programs. The combination of individual conference deals, the College Football playoff television contract, and the NCAA men's basketball tournament television contract has led to billions of dollars in media rights revenue (Fulks, 2017). For intercollegiate athletics administrators, it will continue to be of utmost importance to properly manage the relationships with these existing media companies, as well as establish new relationships with emerging broadcast entities.

Another requirement for those leading athletic departments over the next five to seven years will be to stay abreast of the legal challenges involving the NCAA and its member institutions. While many administrators are trained in the law, it is still important for them to obtain regular updates from their institution's legal counsel, as well as counsel from their conference office and the NCAA. While most of the lawsuits discussed in this study involve the NCAA and/or conferences and not individual institutions, the impact of the results will certainly affect individual institutions and their athletic programs. It will be key for administrators to understand the timelines and potential outcomes of these legal challenges. Additionally, it will be important for NCAA, conference, institution, and athletic leadership to evaluate areas in which they are vulnerable for future legal challenges, while also being cognizant that these challenges can arise in multiple arenas: state legislatures; local, state, and federal courts; and NCAA legislation. Evaluating potential vulnerabilities will allow for the development of strategies to mitigate the challenges before they happen and better defend themselves when they do.

Student-athlete well-being is one area on which athletic department leaders should concentrate in anticipation of these legal challenges. The expert panel forecasted an increase in focus on this area, including forecasting a larger percentage of revenue being devoted to studentathlete well-being. In order for athletic departments to be competitive, a student-athlete centric approach is recommended, one in which resources are devoted to aiding them in their academic pursuits as well their athletic ones. This would entail items such as helping to set up internship and study abroad opportunities, providing better physical and mental health care, and involving student-athletes in more of the decision-making processes. The highest resourced programs are already working on initiatives of this type and if other programs want to compete for the best student-athletes, they will have to adopt a similar approach. Additionally, these are NCAA strategic areas of emphasis (NCAA Division I Board of Directors, 2018), signalling that this is the direction in which programs should be moving in order to maintain NCAA status.

Overall, the results of this study suggest that intercollegiate athletics administrators will need to focus on revenue generation and student-athlete well-being over the next five to seven years if they want to successfully adjust to the changing intercollegiate athletics environment. 
Specifically, it will be imperative for managers to concentrate on new ways to generate revenue and mitigate rising expenses in order to devote additional resources to the student-athlete experience. Furthermore, the preponderance of issues related to revenue generation and studentathlete well-being, as well as how they were rated, support the use of the convergent approach to stakeholder management when it comes to intercollegiate athletics. By rating these issues in this manner, the panel is suggesting that in order to be effective, athletic departments will need to manage stakeholder relationships both for their economic value and their intrinsic value.

\section{Limitations}

The use of the Delphi technique in this study brought with it several inherent limitations. The results of any study using the Delphi technique are not generalizable. The opinions expressed in this study can only be attributed to this group of experts because a purposive sampling method was used. In order to generalize the conclusions that have been drawn in this study, more opinions would need to be gathered. A strategy for this gathering will be discussed in the next section.

Another limitation that stems from the use of the Delphi technique is that the researcher is limited to the information that the experts provide. That is, the level of detail desired may not be reached and to ask for more can potentially compromise the integrity of the results by introducing bias. For instance, in this study the experts forecasted an increase in lawsuits from former studentathletes, but did not specify what kinds of lawsuits. Another area that was in need of more detail was the increase in focus on and resources devoted to student-athlete well-being. Understanding what form this increased focus would take would help to inform preparations on that front and the ripple effects that would impact other areas of the environment. Additionally, the 20 issues that were rated by the expert panel did not present the totality of items generated. If an item was only brought up by one expert, it was not included in the second round.

In addition to the limitations caused by use of the Delphi technique, an underrepresentation from the Group of 5 conferences also limits what can be inferred from these results. There were only two Group of 5 representatives among the 12 participants. It is possible that more issues would have surfaced or that the issues that did come about would have been rated differently if there was a more balanced representation of Power 5 and Group of 5 participants. For instance, this panel of experts did not forecast a decrease in television revenue over the next five to seven years. This is logical for most of the Power 5 conferences because their current television contracts will not expire in that time period. However, this is not the case for all of the Group of 5 conferences and therefore, may have changed that forecast.

\section{Suggestions for Future Research}

There are many directions in which this research can be expanded. Provided below are a few suggestions. These suggestions can be used to obtain results that will further enhance the findings of this current study.

As mentioned in the limitations section, the results of this study are not generalizable. However, one way to obtain results that are applicable to a wider population might be to conduct a survey using the second round instrument from this study (Skulmoski et al., 2007). If one were 
to use the same criteria for participation and include all NCAA Division I FBS programs, the number of participants could easily eclipse the 200 mark. With participation numbers of that magnitude, it would be possible to further verify the forecasts made by the expert panel.

Another way to enhance the results of this current study would be to delve into specific areas in order to obtain greater details on the issues presented here. For instance, the Delphi technique could be employed again with athletic department chief financial officers on the expert panel. This would allow for a deeper exploration of the economic issues. Similarly, a group of legal experts consisting of attorneys who have been involved with litigation involving the NCAA and student-athletes could be used to help determine what areas future lawsuits will come from.

A replication of this study with a different group of stakeholders as the expert panel could also prove enlightening. With the multitude of stakeholders that are connected to intercollegiate athletics, it would be beneficial to obtain at least a few of those perspectives to help prepare for the future. The differing priorities would become evident and this would certainly add to the study of stakeholder theory by allowing researchers to examine how these stakeholder priorities and the reactions to them compare with previous research on stakeholders in intercollegiate athletics (Covell, 2005; Putler \& Wolfe, 1999; Trail \& Chelladurai, 2000).

Finally, an examination of different sectors of the environment would add to the results obtained from this current study. The political sector could be one area of interest. This sector would relate directly to an antitrust exemption, as it would have to be granted by Congress. Furthermore, as state and federal funding for higher education declines, the future impact on intercollegiate athletics could be investigated. Another area worth examining is the technological sector. As mentioned earlier, the intersection between content delivery and emerging technology may greatly impact a significant revenue source for intercollegiate athletics.

The results of this current study combined with these future research suggestions could prove to be valuable tools for leaders in intercollegiate athletics. Ideally, these results can inform leaders on how to optimally position their organizations for efficacy and adaptability in the face of an ever-changing environment. Similarly, scholars can build upon these results to further the study of intercollegiate athletics and stakeholder theory. 


\section{References}

Adler, M., \& Ziglio, E. (1996). Gazing into the oracle: The Delphi method and its application to social policy and public health. London, England: Jessica Kingsley Publishers.

Alston v. National Collegiate Athletic Association, N.D.C.A (2017).

Auerbach, C. F., \& Silverstein, L. B. (2003). Qualitative data: An introduction to coding and analysis. New York, NY: New York University Press.

Baccarne, B., Evens, T., \& Schuurman, D. (2013). The television struggle: An assessment of over-the-top television evolutions in a cable dominant market. Communications and Strategies, 92(4), 43-61.

Berkowitz, S. (2015). NCAA increases value of scholarships in historic vote. USA Today.

Berri, D. (2014). Exploitation is everywhere in men's college basketball. Retrieved from http://time.com/3586037/exploitation-is-everywhere-in-mens-college-basketball/

Branch Jr., D., \& Crow, R. B. (1994). Intercollegiate athletics: Back to the future. Sport Marketing Quarterly, 3(3), 13-21.

Branch, T. (2011). The shame of college sports. Atlantic, 308(3), 80.

Brown, R. W. (1994). Measuring cartel rents in the college basketball player recruitment market. Applied Economics, 26, 27.

Brown, R. W. (2011). Research note: Estimates of college football player rents. Journal of Sports Economics, 12(2), 200-212.

Bryson, J. M. (2011). Strategic planning for public and nonprofit organizations: A guide to strengthening and sustaining organizational achievement. Hoboken, NJ: John Wiley \& Sons. 
Cerritos College. (2016). A brief guide to the analysis of open-ended survey questions. Retrieved from https://cms.cerritos.edu

Chelladurai, P., Inglis, S. E., \& Danylchuk, K. E. (1984). Priorities in intercollegiate athletics: Development of a scale. Research Quarterly for Exercise \& Sport, 55, 74-79.

Cheslock, J. J., \& Knight, D. B. (2015). Diverging revenues, cascading expenditures, and ensuing subsidies: The unbalanced and growing financial strain of intercollegiate athletics on universities and their students. Journal of Higher Education, 86(3), 417-447.

Covell, D. (2005). Attachment, allegiance and a convergent application of stakeholder theory: Assessing the impact of winning on athletic donations in the Ivy League. Sport Marketing Quarterly, 14(3), 168.

Daft, R. L. (2004). Organization theory and design. Mason, OH: Thomson/South-Western.

Dalkey, N. C. (1967). Delphi. RAND Corporation.

Dalkey, N., \& Helmer, O. (1963). An experimental application of the Delphi method to the use of experts. Management Science, 9(3), 458-467.

Davidson, P. L. (2013). The Delphi technique in doctoral research: Considerations and rationale. Review of Higher Education \& Self-Learning, 6(22), 53-65.

Delbecq, A. L., Van de Ven, A. H., \& Gustafson, D. H. (1975). The Delphi technique. Group techniques for program planning: A guide to nominal group and Delphi processes (pp. 83106). Glenview, Ill.: Scott, Foresman.

Denhart, M., Ridpath, D., \& Vedder, R. (2011). Funding the arms race: A case study of student athletic fees. Center for College Affordability and Productivity.

Dennie, C. (2012). Changing the game: The litigation that may be the catalyst for change in intercollegiate athletics. Syracuse Law Review, 62, 15-51. 
Dodd, D. (2016). College teams becoming copycats as gap between haves, have-nots widens. Retrieved from https://www.cbssports.com/college-football/news/college-teamsbecoming-copycats-as-gap-betweens-haves-have-nots-widens/

Drain, T. S., \& Ashley, F. B. (2000). Intercollegiate athletics: Back to the future II: A comparison with branch and crow five years later. Sport Marketing Quarterly, 9(2), 77.

Dunn, J. M. (2013). Should the playing field be leveled? Funding inequities among division I athletic programs. Journal of Intercollegiate Sport, 6, 44-51.

Franklin, K. K., \& Hart, J. K. (2007). Idea generation and exploration: Benefits and limitations of the policy Delphi research method. Innovative Higher Education, 31(4), 237-246.

Fulks, D. L. (2017). NCAA revenues / expenses division I report 2004 - 2016. Indianapolis, IN: NCAA.

Gibbs, G. (2007). Analyzing qualitative data. Los Angeles, CA: SAGE Publications.

Glaister, K. W., \& Falshaw, J. R. (1999). Strategic planning: Still going strong? Long Range Planning, 32, 107-116.

Gnatzy, T., Warth, J., von der Gracht, H. \& Darkow, I. L. (2011). Validating an innovative realtime Delphi approach: A methodological comparison between real-time and conventional Delphi studies. Technological Forecasting \& Social Change, 78(9), 1681-1694.

Hobson, W., \& Rich, S. (2015). Playing in the red. The Washington Post. Retrieved from https://www.washingtonpost.com/sf/sports/wp/2015/11/23/running-up-thebills/?noredirect=on\&utm_term=.3173927571bd

Hosick, M. B. (2014). Council approves meals, other student-athlete well-being rules. Retrieved from www.ncaa.org

Hosick, M. B. (2017). DI student-athletes to have more time away from sports. Retrieved from www.ncaa.org 
Hsieh, H., \& Shannon, S. (2005). Three approaches to qualitative content analysis. Qualitative Health Research, 15(9), 1277-1288.

Hsu, C., \& Sandford, B. A. (2007). The Delphi technique: Making sense of consensus. Practical Assessment, Research \& Evaluation, 12(10), 1-8.

Jenkins v. National Collegiate Athletic Association, N.D.C.A (2014).

Keller v. Electronic Arts, Inc, N.D.C.A (2009).

LeRoy, M. H. (2015). Courts and the future of "athletic labor" in college sports. Arizona Law Review, 57(2), 475-521.

Litan, R., \& Keith, T. (2014). Legal briefs. Sports Illustrated, 120(22), 14-15.

Ludwig, B. (1997). Predicting the future: Have you considered using the Delphi methodology. Journal of Extension, 35(5), 1-4.

Makridakis, S. G. (1990). Forecasting, planning, and strategy for the 21st century. New York, NY: Free Press; Collier Macmillan.

Matheson, V. A., O'Connor, D. J., \& Herberger, J. H. (2012). The bottom line: Accounting for revenues and expenditures in intercollegiate athletics. International Journal of Sport Finance, 7, 30-45.

Mitchell, M., Leachman, M., \& Masterson, K. (2016). Funding down, tuition up: State cuts to higher education threaten quality and affordability at public colleges. Washington D. C.: Center on Budget and Policy Priorities.

Morton, J. T. (2017). Impact of student fees on winning in the NCAA. Journal of Contemporary Athletics, 11(2), 73-82.

NCAA. (2014). Division I steering committee on governance recommended governance model. Retrieved from http://www.ncaa.org 
NCAA. (2015). Who we are. Retrieved from http://www.ncaa.org/about/who-we-are

NCAA. (2018). NCAA division one manual. Indianapolis, IN: National Collegiate Athletic Association.

NCAA Division I Board of Directors. (2018). Strategic areas of emphasis 20182023. Indianapolis, IN: National Collegiate Athletic Association. Retrieved from http://www.ncaa.org/governance/ncaa-division-i-board-directors-strategic-areasemphasis-2018-2023

New, J. (2017). A true day off. Inside Higher Ed. Retrieved from https://www.insidehighered.com/news/2017/01/23/power-five-leagues-adopt-new-ruleslessening-time-demands

O’Bannon v. National Collegiate Athletic Association, N.D.C.A (2014).

Oliver v. Baratta, C.C.O.H (2008).

Pastore, D. L., \& Schneider, R. G. (2004). Past and future predictions of NCAA division I intercollegiate athletics. International Journal of Sport Management, 5(2), 183.

Putler, D. S., \& Wolfe, R. A. (1999). Perceptions of intercollegiate athletic programs: Priorities and tradeoffs. Sociology of Sport Journal, 16(4), 301-325.

Rådestad, M., Rüter, A., Gryth, D., Svensson, L., Jirwe, M., \& Castrén, M. (2013). Essential key indicators for disaster medical response suggested to be included in a national uniform protocol for documentation of major incidents: A Delphi study. Scandinavian Journal of Trauma, Resuscitation and Emergency Medicine, 21, 1-11.

Rishe, P. (2015). Examining the decline in college football attendances: Do remedies exist? Retrieved from https://www.forbes.com/sites/prishe/2015/12/22/examining-thedecline-in-college-football-attendances-do-remedies-exist/\#582e20417df4

Rothaermel, F. T. (2017). Strategic management. New York, NY: McGraw-Hill. 
Rowe, G., \& Wright, G. (1999). The Delphi technique as a forecasting tool: Issues and analysis. International Journal of Forecasting, 15(4), 353-375.

Rowe, G., \& Wright, G. (2001). Expert opinions in forecasting: The role of the Delphi technique. In Principles of forecasting (pp. 125-144). Springer, Boston, MA.

Saldaña, J. (2016). The coding manual for qualitative researchers. Thousand Oaks, CA: Sage.

Skulmoski, G., Hartman, F., \& Krahn, J. (2007). The Delphi method for graduate research. Journal of Information Technology Education: Research, 6, 1-21.

Slack, T., \& Parent, M. M. (2006). Understanding sport organizations: The application of organization theory. Champaign, IL: Human Kinetics.

Smith, R. A. (2011). Pay for play: A history of big-time college athletic reform. Urbana, IL: University of Illinois Press.

Solomon, J. (2014). Schools can give out 4-year athletic scholarships, but many don't. Retrieved from https://www.cbssports.com/college-football/news/schools-can-give-out-4-yearathletic-scholarships-but-many-dont/

Suri, H. (2011). Purposeful sampling in qualitative research synthesis. Qualitative Research Journal, 11(2), 63-75. doi:10.3316/QRJ1102063

Trail, G., \& Chelladurai, P. (2000). Perceptions of goals and processes of intercollegiate athletics: A case study. Journal of Sport Management, 14(2), 154-178.

United States Department of Education. (n.d.). Title IX and sex discrimination. Retrieved from http://www2.ed.gov/about/offices/list/ocr/docs/tix_dis.html

Van Rheenen, D. (2011). Exploitation in the American academy: College athletes and selfperceptions of value. The International Journal of Sport \& Society, 2(4), 11-26. 
Van Rheenen, D. (2013). Exploitation in college sports: Race, revenue, and educational reward. International Review for the Sociology of Sport, 48(5), 550-571. doi: $10.1177 / 1012690212450218$

von der Gracht, H. A. (2012). Consensus measurement in Delphi studies: Review and implications for future quality assurance. Technological Forecasting and Social Change, 79(8), 1525-1536.

Weaver, A. G. (2015). New policies, new structure, new problems-reviewing the NCAA's autonomy model. Elon Law Review, 7, 551.

White v. National Collegiate Athletic Association, C.D.C.A (2006).

Witcher, B. J., \& Chau, V. S. (2010). Strategic management: Principles and practice. Boston, MA: Cengage Learning EMEA.

Wolf, C., \& Floyd, S. W. (2013). Strategic planning research: Toward a theory-driven agenda. Journal of Management, 43(6), 1754-1788.

Wolfe, R., Hoeber, L., \& Babiak, K. (2002). Perceptions of the effectiveness of sport organisations: The case of intercollegiate athletics. European Sport Management Quarterly, 2(2), 135-156.

Wolfe, R., \& Putler, D. S. (2002). How tight are the ties that bind stakeholder groups? Organization Science, 13, 64-80.

Wolverton, B. (2014). Autonomy for rich NCAA programs won't please everyone. Chronicle of Higher Education, 60(44), A14.

Wolverton, B., \& Kambhampati, S. (2015). Colleges raised a record \$1.26-billion for sports in 2014. Chronicle of Higher Education, 61(20).

Wright, C., Eagleman, A. N., \& Pedersen, P. M. (2011). Examining leadership in intercollegiate athletics: A content analysis of NCAA division I athletic directors. Choregia, 7(2), 35-52. 
Wushanley, Y. (2004). Playing nice and losing: The struggle for control of women's intercollegiate athletics, 1960-2000. Syracuse, NY: Syracuse University Press.

Yousuf, M. I. (2007). Using experts' opinions through Delphi technique. Practical Assessment, Research \& Evaluation, 12(4), 1-8.

Yow, D. A., Migliore, R.H., Bowden, W. W., Stevens, R. E., \& Loudon, D. L. (2000). Strategic planning for college athletics. Philadelphia, PA: The Haworth Press, Inc.

Zimbalist, A. (2013). Inequality in intercollegiate athletics: Origins, trends and policies. Journal of Intercollegiate Sport, 6, 5-24. 
Appendix A

Future Issues in Intercollegiate Athletics

First Round Questionnaire

1. What conference is your institution affiliated with?

- American Athletic Conference

- Atlantic Coast Conference

- Big Ten Conference

- Big 12 Conference

- Conference USA

- Mid-American Conference

- Mountain West Conference

- Pac-12 Conference

- Southeastern Conference

○ Sun Belt Conference

2. Gender

○ Male

○ Female

3. Race
○ White
- Black or African American
- American Indian or Alaska Native
- Asian
- Hispanic or Latino
- Native Hawaiian or Pacific Islander
O Other

4. Years of experience in intercollegiate athletics
○ 1-5
○ 6-10
○ 11-15
○ Over 15

5. Years holding current title
○ 1-5
○ 6-10
- 11-15
○ Over 15 
6. What are the most important issues FBS athletic departments will need to prepare for over the next five to seven years?

7. In what ways will the autonomy of the Power 5 conferences impact how FBS athletic departments generate revenue and allocate resources over the next five to 10 years?

8. How will the autonomy of the Power 5 conferences impact the number and type of lawsuits FBS athletic departments will be involved with over the next five to 10 years?

9. In what ways will the autonomy of the Power 5 conferences impact how FBS studentathletes are compensated over the next five to 10 years?

10. In what ways will the autonomy of the Power 5 conferences impact the balance between academics and athletics for FBS athletic departments over the next five to 10 years?

11. In what ways will the autonomy of the Power 5 conferences impact the diversity of administration and coaching personnel in FBS athletic departments over the next five to 10 years?

12. In what ways will the current litigation facing the NCAA and its member institutions impact how FBS athletic departments generate revenue and allocate resources over the next five to 10 years?

13. In what ways will the current litigation facing the NCAA and its member institutions impact legal strategies of FBS athletic departments over the next five to 10 years?

14. In what ways will the current litigation facing the NCAA and its member institutions impact how FBS student-athletes are compensated over the next five to 10 years?

15. In what ways will the current litigation facing the NCAA and its member institutions impact the balance between academics and athletics for FBS athletic departments over the next five to 10 years?

16. In what ways will the current litigation facing the NCAA and its member institutions impact the diversity of administration and coaching personnel in FBS athletic departments over the next five to 10 years? 